\title{
Experimental Research on Treatment of Greywater using a Prototype
}

\author{
S.Christopher Gnanaraj, Ramesh Babu Chokkalingam, S.K.M. Pothinathan, R.Rekha
}

\begin{abstract}
Water is principal standard resource brought by nature. Freshwater deficiency is a noteworthy issue impacts no less than one fifth of the aggregate masses and more will be affected on account of people advancement. Now a days the openness of consumable water isn't abundant. Hence to satisfy the need and demand, the best course of action is reusing, and treatment of family wastewater except an irreplaceable part for the human activities. We pick diminish water reuse and stimulate near bore well. For this examination unrefined water and bore water is accumulated from three one of a kind domain, which is attempted by physical and naturally while treating. This ask about expected to consider the efficiencies of unravel treatment for greywater reuse with three models using fine aggregates, various sizes of coarse aggregate, powdered activated carbon in view of quick sand channel thought and complexity and bore water standards. Physic-blend parameters viz. turbidity, pH, CHEMICAL OXYGEN DEMAND (COD), DISSOLVED OXYGEN (DO), Total dissolved solids (TDS), Conductivity, Hardness and alkalinity were penniless down. Organic parameters including coli form were finished by two strategies. The empirical formulas were additionally developed utilizing this investigation. The correlation between's pH-turbidity, pH-EC, pH-DO, $\quad$ H-BOD, turbidity-Hardness, turbidity-DO, turbidity-BOD, turbidity-COD, BOD-DO, BOD-COD were derived. The expulsion proficiency of $\mathrm{pH}$, turbidity, hardness, ELECTICAL CONDUCTIVITY $(E C), \quad$ DISSOLVED OXYGEN(DO), BIOLOGICAL OXYGEN DEMAND(BOD) and CHEMICAL OXYGEN DEMAND(COD) were between 50\% $90 \%, 75 \%-90 \%, 70 \%-85 \%, 50 \%-90 \%, 85 \%$ - 99\%, $70 \%$ - $90 \%$ and $55 \%-90 \%$ individually. It is a convincing system for treatment of diminish water when appeared differently in relation to the standard method so it can be executed on little scale at houses, structures et cetera. The result get also nearer to the ground water of different sources. The best level of capability were high, showing the capacity of the structure, and proposing their change keeping in mind the end goal to achieve ordinary viability.
\end{abstract}

Keywords: About four key words or phrases in alphabetical order, separated by commas.

Revised Manuscript Received on December 30, 2019.

* Correspondence Author

S.Christopher Gnanaraj*, Department of Civil Engineering, Kalasalingam Academy of Research and Education, Virudhunagar, India. Email: s.christophergnanaraj@klu.ac.in

Ramesh Babu Chokkalingam, Department of Civil Engineering, Kalasalingam Academy of Research and Education, Virudhunagar, India.

Email: c.rameshbabu@klu.ac.in

S.K.M. Pothinathan, Department of Civil Engineering, Kalasalingam Academy of Research and Education, Virudhunagar, India.

Email: s.k.m.pothinathan@klu.ac.in

R.Rekha, Department of Civil Engineering, Kalasalingam Academy of Research and Education, Virudhunagar, India.

Email: strekha1999@gmail.com

\section{INTRODUCTION}

Water is important natural resource brought by nature. $70 \%$ of global surface is surrounded by water only $30 \%$ are fresh water ${ }^{[5]}$. Now-a-days the availability of potable water is not abundant the amount of water available for use on the planet is very finite. To satisfy the needs and demand the best solution is recycling and treatment of household wastewater because of less contamination. Grey water is the type of wastewater from the household with low contaminations. Grey water is also termed as sullage [1], gets its name from its cloudy appearance and from its status as being neither fresh nor heavily polluted. Sullages have less impurity compared to black water. The Grey water includes bath, shower, hand basin, washing, and kitchen wastewater [2]. Some author removed kitchen wastewater for consideration. The contaminants like disease causing organisms. Chemical from soap, detergents, shampoo, dyes, mouthwash, toothpaste etc. Common contaminants present in grey water are salts, food particles, oil, surfactants, microorganisms [10] Ground water plays a vital role for the human activities. 50-80\% of the total household wastewater is greywater [1,3]. Greywater represents up to $70 \%$ of total consumed water but contains only $30 \%$ of the organic fraction and 9 to $20 \%$ of the nutrients [5]. Organic loading is the major difference between greywater and sewage. The cost of treatment is less due to low level of treatment includes sedimentation, filtration and adsorption applied to the greywater. The possible reuse option for the treated water are urinal and toilet flushing, irrigation of lawns, washing of vehicles and windows, and preserve wetlands, recharge into ground, agriculture and etc. Despite the relatively low concentration of contaminants, greywater constituents are known to be recalcitrant [7]. It additionally diminishes the reliance on huge foundations, for example, dams and desalination exchange plants in this way enhancing the nature of freshwater biological systems and lessening clashes over water assets [14]. Reusing of grey water will secure the amphibian biological systems by diminishing the preoccupations of freshwater, lessening the amount of supplements and other dangerous contaminants entering conduits [15]. Grey water regularly contains a different pathogens, Grey water safe utilize requires some $\mathrm{cl}$ eansing [16]. At the point when grey water is appropriately overseen, it can be a profitable asset for both cultivation and agribusiness producers [17]. The guidelines for dim water reusing relies upon area, application, it typically incorporates parameters, for example, natural, solids and microbiological substance of the water [18]. 
The contaminants that can be found in grey water involve an expansive scope of xenobiotic substance which is an engineered synthetic, including both natural polluting influences and metals [19]. The advantages of reusing Sullage incorporates crisp water extraction, not very many effect on septic tank, ground water energize, security of ground water table [37]. The reuse of greywater in many parts of the world helps to reduce the usage of potable water by up to $50 \%$, sewage generations and it reduces money and increasing the effective water supply in regions where demand of water is more. Reuse of grey water can be added to the existing water source. Particularly in arid climatic region [4] Reuse of greywater for on-site irrigation is becoming a common practice in entire worldwide, particularly in areas that face water demand. The experimental ideas is to treating of greywater to nearby bore well to satisfy the demand by the concept of rapid sand filter [29] with activated carbon treatment and finding its efficiency and empirical formulas

\section{MATERIAL STUDY}

\section{COARSE AGGREGATE}

Coarse aggregates are frequently used to retain coarse particles and to sufficiently reduce turbidity. Coarse layer used as a filter medium. It can be replaced upon cleaning. such pre-filtration can be done either horizontally or vertically. The filtration rates for a coarse filter are lower than those for a conventional filter. The different sizes of coarse aggregates are 6-12mm, $12-20 \mathrm{~mm}, 20-40 \mathrm{~mm}$ were sieved then washed 10 times and dried for sometimes and used to fill in the filter for respective depth as per referred journal.

\section{B. FINE AGGREGATE}

Fine aggregate works as a physical strainer, a biological renovator and a biological recycler of all wastewater passing through the layer. Sand's moisture, temperature, acidity and nutrient will make the pathogens present in water to die. The final aggregates of sizes $1 \mathrm{~mm}$ was collected by sieve and washed for multi time to remove the dust and dried for sometimes and used to fill in the filter as per respective referred by journal.

\section{ACTIVATED CARBON}

Activated carbon has been used as a water filtering medium for purification of water, which was kept inside the cotton rolls in between the layer of fine aggregates. The purpose of activated carbon is used primarily to remove taste and odor.The powdered activated carbon to remove dissolved organics It was widely used for removal contaminants in water due to their high capacity for adsorption.it can remove the total suspended solids and BOD effectively over $99 \%$ to $1 \mathrm{mg} / \mathrm{l}$ and also improves the taste and odour of the water.

Physical Adsorption - During this process, the adsorbates are held on the surface of the pore walls by weak forces of attraction known as Van Der Waals Forces or London dispersion forces.

Chemisorption - This involves relatively strong forces of attraction, actual chemical bonds between adsorbates and chemical complexes on the pore wall of the activated carbon.

\section{EXPERIMENTAL SET UP}

This setup was done with the grey water, as per the journal on the rapid sand filter with activated carbon concept which is collected from three different household greywater. The setup was constructed by PVC pipe. The model of this filter is a circular pipe of $90 \mathrm{~mm}$ with $2 \mathrm{~m}$ long. For this setup we used different size of coarse aggregate, fine aggregate, and powdered activated carbon. The size of the aggregates are listed by, For coarse aggregate $20-40 \mathrm{~mm}, 12-20 \mathrm{~mm}$, $6-12 \mathrm{~mm}$. For fine aggregate $1 \mathrm{~mm}$ and addition to that activated carbon. The arrangement of the setup in the following order first layer is followed by $20 \mathrm{~mm}$ of $20 \mathrm{~cm}$ second layer is about $12 \mathrm{~mm}$ of $20 \mathrm{~cm}$ and followed by $6 \mathrm{~mm}$ of $20 \mathrm{~cm}$ aggregates next layer by fine aggregate of $10 \mathrm{~cm}$ and activated carbon layer. For separating this layer plastic screens are used. The inlet and outlet are fitted with top and bottom end of the pipe. The treated grey water will be collected in the separate container.

Table 3.1 Experimental setup

\begin{tabular}{|c|c|c|c|c|}
\hline S.No & Layer & Arrangement & Depth & $\begin{array}{l}\text { Size And } \\
\text { Material }\end{array}$ \\
\hline 1 & $1^{\text {th }}$ & horizontal & $10 \mathrm{~cm}$ & $1 \mathrm{~mm}$ aggregates \\
\hline 2 & $2^{\text {nd }}$ & horizontal & $20 \mathrm{~cm}$ & $\begin{array}{c}\text { 6-12mm } \\
\text { aggregates }\end{array}$ \\
\hline 3 & $3^{\text {rd }}$ & horizontal & $20 \mathrm{~cm}$ & $\begin{array}{c}12-20 \mathrm{~mm} \\
\text { aggregates }\end{array}$ \\
\hline 4 & $4^{\text {th }}$ & horizontal & $20 \mathrm{~cm}$ & $\begin{array}{c}20-40 \mathrm{~mm} \\
\text { aggregates }\end{array}$ \\
\hline 5 & $5^{\text {th }}$ & Vertical & $10 \mathrm{~cm}$ & $\begin{array}{l}1 \mathrm{~mm} \text { aggregates } \\
\text { and powdered } \\
\text { activated carbon }\end{array}$ \\
\hline 6 & $6^{\text {th }}$ & Vertical & $20 \mathrm{~cm}$ & $\begin{array}{c}6-12 \mathrm{~mm} \\
\text { aggregates }\end{array}$ \\
\hline 7 & $7^{\text {th }}$ & Vertical & $20 \mathrm{~cm}$ & $\begin{array}{c}12-20 \mathrm{~mm} \\
\text { aggregates }\end{array}$ \\
\hline 8 & $8^{\text {th }}$ & Vertical & $20 \mathrm{~cm}$ & $\begin{array}{c}\text { 20-40mm } \\
\text { aggregates }\end{array}$ \\
\hline
\end{tabular}

\section{WORKING OF MODEL}

A litre of grey water is poured in the top of sand layer arranged in the horizontal bed. The water simply flows through the sand layer, then followed by coarse aggregate of three different sizes. If any suspended particles present in the greywater are left behind in the top layer of sand easily and contaminants starts removed in this layer, till the course aggregate layer. It takes some time to filter for purify, the Flowing water through the horizontal bed. After passes through the horizontal bed layer of the filter, it reaches the vertical bed layer which contains sand layer, coarse 
aggregate as same as that of horizontal bed layer but it contains additional layer of activated carbon in between the sand layer.

\section{TESTS AND DISCUSSIONS}

\section{A. $\mathbf{p H}$}

The $\mathrm{pH}$ of grey water before treatment are 8.3,7.3 and 7.9 and the value after treating the water values ranges between 6.9 to 7.5 . The permissible limit for potable water standards is 6.5-8.5.

\section{B. TURBIITY}

Turbidity is due to the suspended particles. The turbidity of greywater before treatment are $287,130,110$ and the values after treating the values obtain from 20 -70, The permissible limit for potable water is 10 .

\section{HARDNESS}

The hardness present in the greywater before the treatment were 45,52,47 and hardness after the treatment ranges from 15-25. The permissible limit for potable water is 500

\section{ELECTICAL CONDUCTIVITY(EC)}

The electrical conductivity in the greywater before the treatment were 540,280,240 and after the treatment $t$ ranges from 180-450. When EC is less than 500 there is no detrimental effect on plants.

\section{E. DISSOLVED OXYGEN (DO)}

In raw water and domestic wastes. Dissolved oxygen is the factor which determines whether the biological processes undergoing a change are aerobic and anaerobic. It is a single test which will immediately indicate the sanitary status of streams. The dissolved oxygen present in the greywater before the treatment were 4.8,5.2,4.2 and after the treatment it ranges from 1.4-2. The permissible limit for the potable water is $40 \%$ saturation

\section{F. BIOLOGICAL OXYGEN DEMAND (BOD)}

The BOD is the amount of oxygen require by bacteria while stabilizing decomposable organic matter under aerobic conditions. Polluted water does not contain sufficient oxygen in solution to maintain aerobic condition during decomposition. BOD present in the greywater before treatment were 3.84,4.3,3.3 and after treatment it ranges from 0.5-4.3.

\section{G. CHEMICAL OXYGEN DEMAND (COD)}

The COD test is based on the concept that a large majority of organic compounds can be completely oxidized by the action of strong oxidizing agent in acidic medium. The quantity of oxygen require is proportional to organic matter. The COD present in the greywater before the treatment were $600,500,400$ and after the treatment the value ranges from 130-300.

\section{H. BIOLOGICAL TESTING}

Coliform testing is done for both the untreated sample and treated sample and measure the bacteria count. The result obtained was 102 count and in untreated water it is nil. The bacterial count is also measured by the glass plates. The procedures described in this protocol, we should able to perform plating procedures without contaminating media.
Isolate single bacterial colonies by the streak-plating method. Use pour plating and spread plating methods to determine the concentration of bacteria. Perform soft agar overlays when working with phage. The presence of bacteria in un treated water is resulted as 120 counts whereas after treating the result found was nil presence of bacteria.

Table 5.1 Test Results

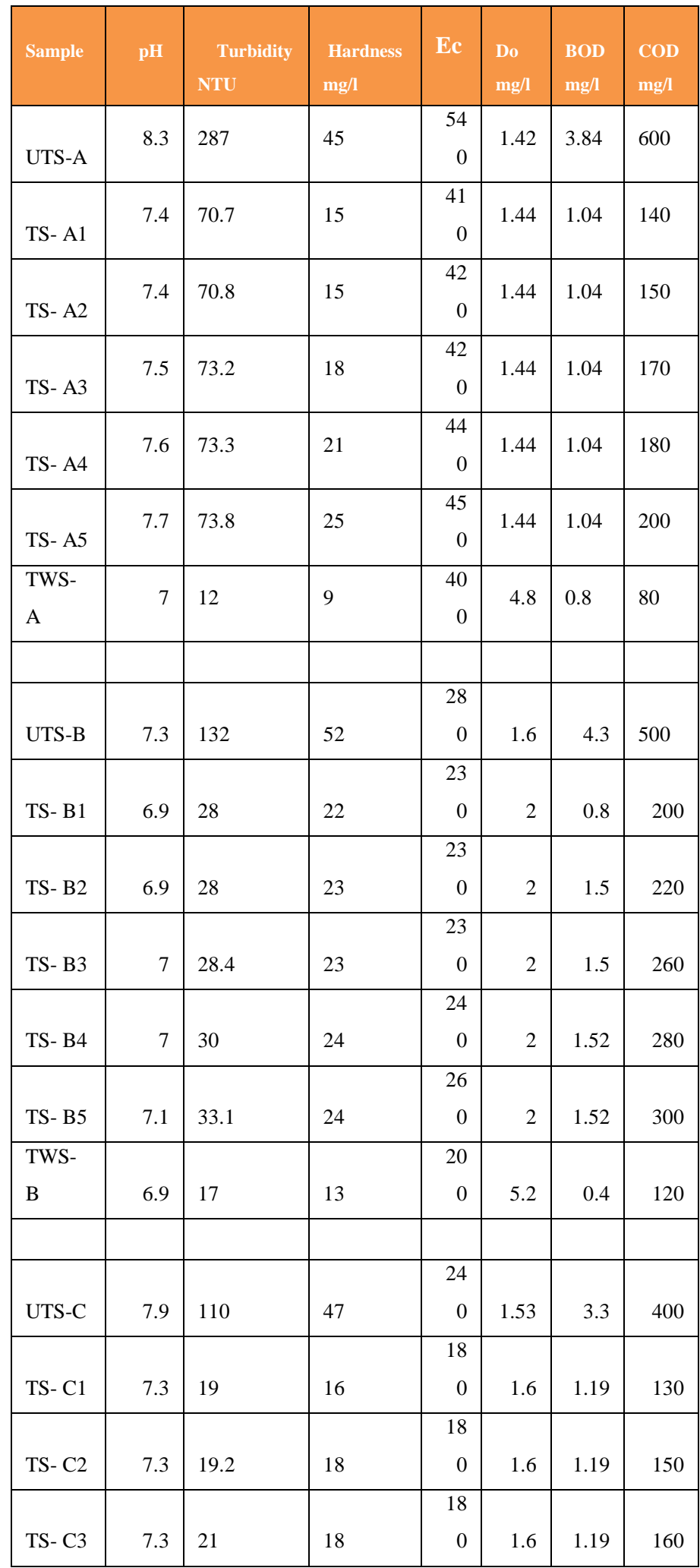




\begin{tabular}{|l|r|l|l|r|r|r|r|}
\hline TS- C4 & 7.4 & 26 & 19 & 0 & 19 & 1.19 & 180 \\
\hline
\end{tabular}

\begin{tabular}{|c|c|c|c|c|c|c|c|}
\hline Sample & $\mathrm{pH}$ & $\begin{array}{l}\text { Turbidit } \\
\mathrm{y}\end{array}$ & $\begin{array}{l}\text { Hardnes } \\
\mathrm{s}\end{array}$ & $\mathrm{EC}$ & DO & & COD \\
\hline TS- A1 & 69.23 & 78.65 & 83.33 & 92.86 & 99.41 & & 88.46 \\
\hline TS- A2 & 69.23 & 78.62 & 83.33 & 85.71 & 99.41 & & 86.54 \\
\hline TS- A3 & 61.54 & 77.75 & 75.00 & 85.71 & 99.41 & & 82.69 \\
\hline TS- A4 & 53.85 & 77.71 & 66.67 & 71.43 & 99.41 & & 80.77 \\
\hline TS- A5 & 46.15 & 77.53 & 55.56 & 64.29 & 99.41 & & 76.92 \\
\hline TS- B1 & $\begin{array}{r}100.0 \\
0\end{array}$ & 90.43 & 76.92 & 62.50 & 88.89 & & 78.95 \\
\hline TS- B2 & $\begin{array}{r}100.0 \\
0 \\
\end{array}$ & 90.43 & 74.36 & 62.50 & 88.89 & & 73.68 \\
\hline TS- B3 & 75.00 & 90.01 & 74.36 & 62.50 & 88.89 & & 63.16 \\
\hline TS- B4 & 75.00 & 88.70 & 71.18 & 50.00 & 88.89 & & 58.00 \\
\hline TS- B5 & 50.00 & 86.00 & 71.18 & 25.00 & 88.89 & & 52.63 \\
\hline TS- C1 & 85.71 & 95.79 & 81.58 & 66.67 & 97.38 & & 87.10 \\
\hline TS- C2 & 85.71 & 95.79 & 76.32 & 66.67 & 97.38 & & 80.65 \\
\hline TS- C3 & 85.71 & 93.69 & 76.32 & 66.67 & 97.38 & & 77.42 \\
\hline TS- C4 & 71.43 & 88.42 & 73.68 & 55.56 & 97.38 & & 70.97 \\
\hline TS- C5 & 71.43 & 85.26 & 73.68 & 55.56 & 97.38 & & 64.52 \\
\hline TS- C5 & 7.4 & & 19 & $\begin{array}{r}19 \\
0\end{array}$ & 1.6 & 1.19 & 200 \\
\hline $\begin{array}{l}\text { TWS- } \\
\text { C }\end{array}$ & 7.2 & & 9 & $\begin{array}{r}15 \\
0\end{array}$ & 4.3 & 0.52 & 90 \\
\hline
\end{tabular}

*UTS - Untreated sample *TS - Treated sample *TWS - tap water Sample A, B, C-Sample 1,2,3 . A1- $1^{\text {st }}$ trial of $1^{\text {st }}$ sample

A2- $6^{\text {th }}$ trial of $1^{\text {st }}$ sample, A3- $11^{\text {th }}$ trail of $1^{\text {st }}$ sample etc..

\section{TREATING EFFICIENCY}

\begin{tabular}{|c|c|c|}
\hline S.NO & PARAMETER & EMPIRICAL EQUATION \\
\hline 1. & $\mathrm{pH}$ & $\begin{array}{c}y=-0.0083 x^{3}+0.0893 x^{2}- \\
0.2024 x+7.52\end{array}$ \\
\hline 2. & Turbidity & $\begin{array}{l}y=0.3042 x^{4}-3.8083 x^{3}+ \\
16.396 x^{2}-26.992 x+84.8\end{array}$ \\
\hline 3. & Hardness & $y=0.5714 x^{2}-0.8286 x+15$ \\
\hline 5. & DO & $y=2$ \\
\hline 6. & BOD & $\begin{array}{l}y=-0.0317 x^{4}+0.4367 x^{3}- \\
2.1783 x^{2}+4.6533 x-2.08\end{array}$ \\
\hline 7. & COD & $y=26 x+174$ \\
\hline
\end{tabular}

The efficiency of the treatment for various properties were studied and the results were as follows $\mathrm{pH}$, turbidity, hardness, EC, DO, BOD, COD ranges 50\%-99\%, 75\%-90\%, $70 \%-85 \%, 50 \%-90 \%, 85 \%-95 \%, 5 \%-90 \%$

Table 6.1TREATING EFFICIENCY

\section{EMPIRICAL EQUATIONS TO FIND THE WATER QUALITY PARAMETERS AT $\mathbf{N}^{\mathrm{TH}}$ TRIAL:}

Equations have been developed to get the value of various parameter ( $\mathrm{pH}$, turbidity, hardness, EC, DO, BOD, COD) after $\mathrm{N}^{\text {th }}$ Trial based on the results obtained from $1^{\text {st }}, 6^{\text {th }}, 11^{\text {th }}$, $16^{\text {th }}$ and $21^{\text {st }}$ trial.

From this equation, $\mathrm{x}$ value be the number of trials for all 1-7(s.no.) the water used to treat, Here mentioned the interval of five trails such as $1^{\text {st }}, 6^{\text {th }}, 11^{\text {th }}, 16^{\text {th }}, 21^{\text {th }}$ etc. $y$ be the value get by the equation using $x$. $y$ value is to find the value of 1.pH.2.turbidity,3.hardness,4. Electrical conductivity,5. DO, 6 . BOD and 7. COD respectively

Table 7.1 EMPIRICAL EQUATION TO FIND THE WATER QUALITY PARAMETERS AT $\mathrm{n}^{\text {th }}$ TRIAL.

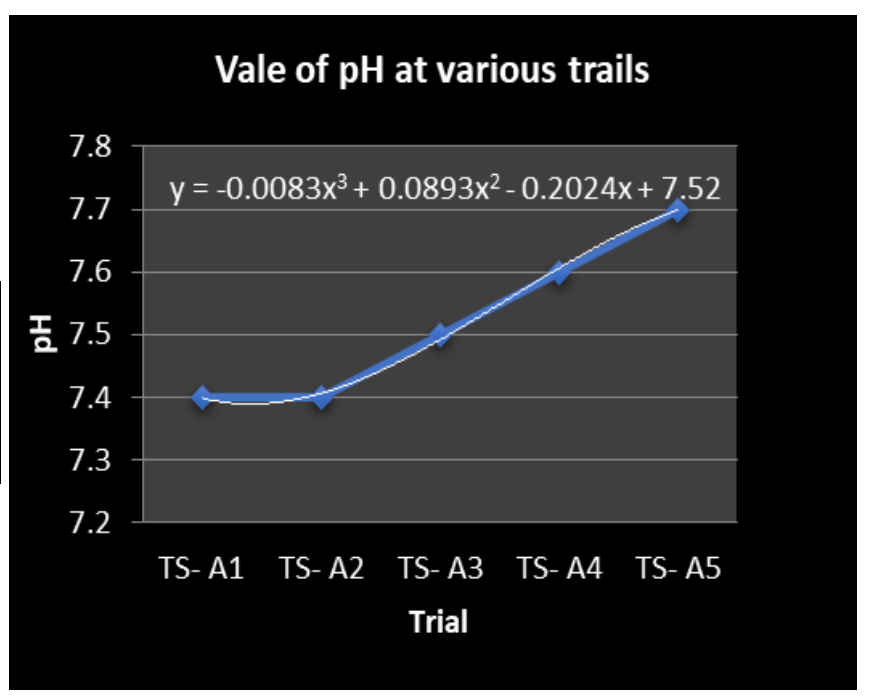

Fig 7.1Vale of pH at various trails

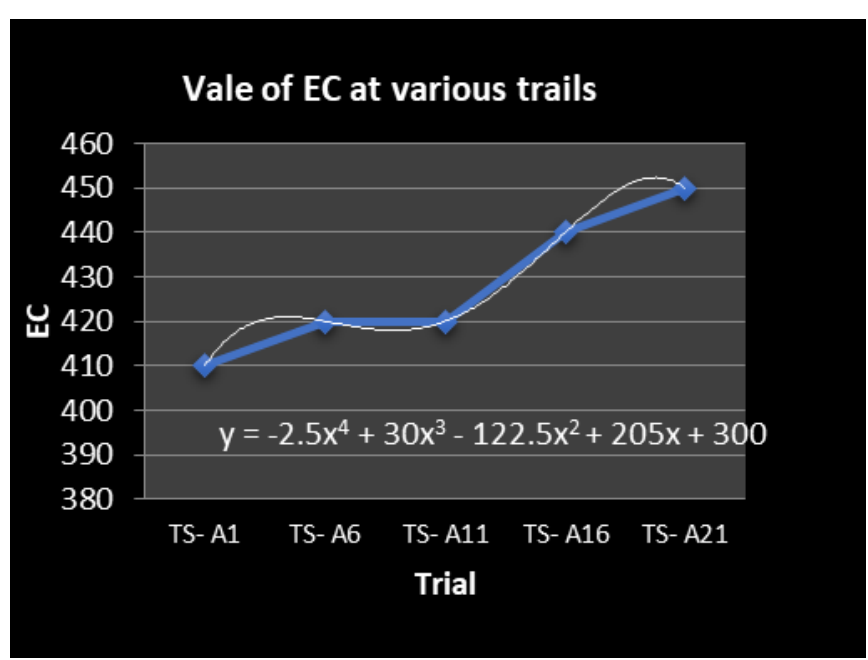

Fig 7.2Vale of EC at various trails 


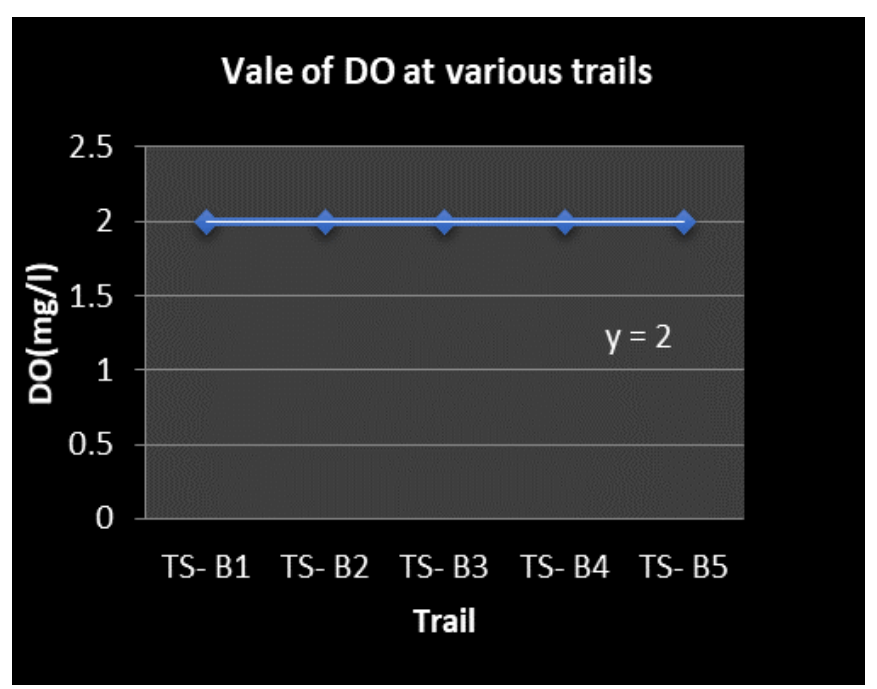

Fig 7.3Vale of DO at various trails

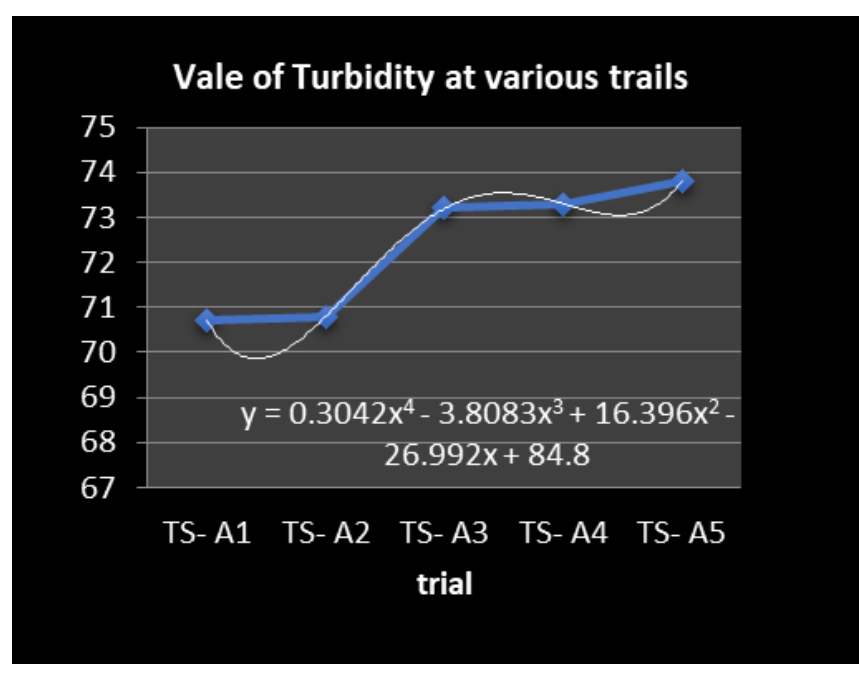

Fig 7.4Vale of Turbidity at various trails

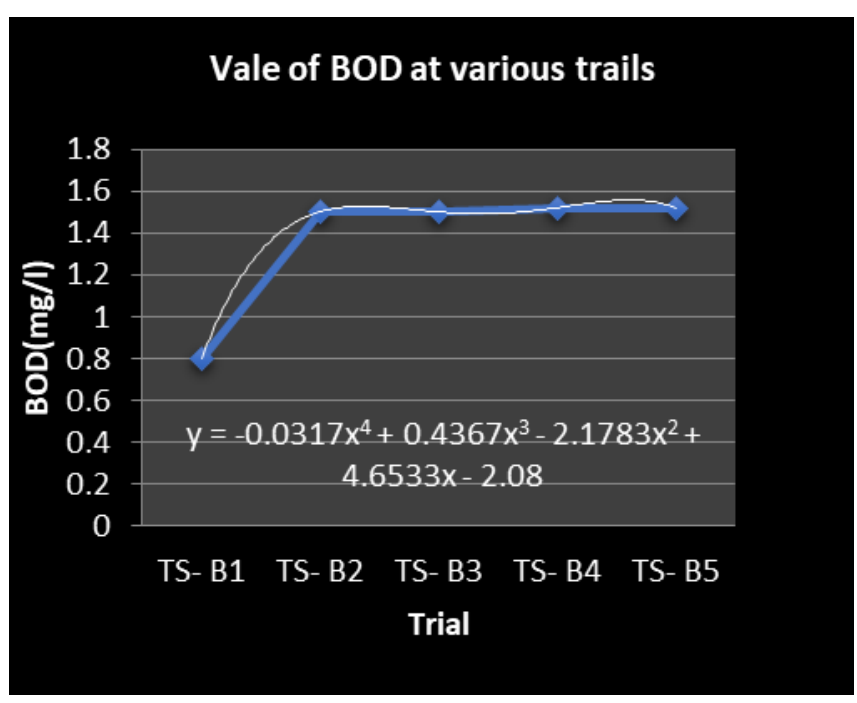

Fig 7.5Vale of BOD at various trails

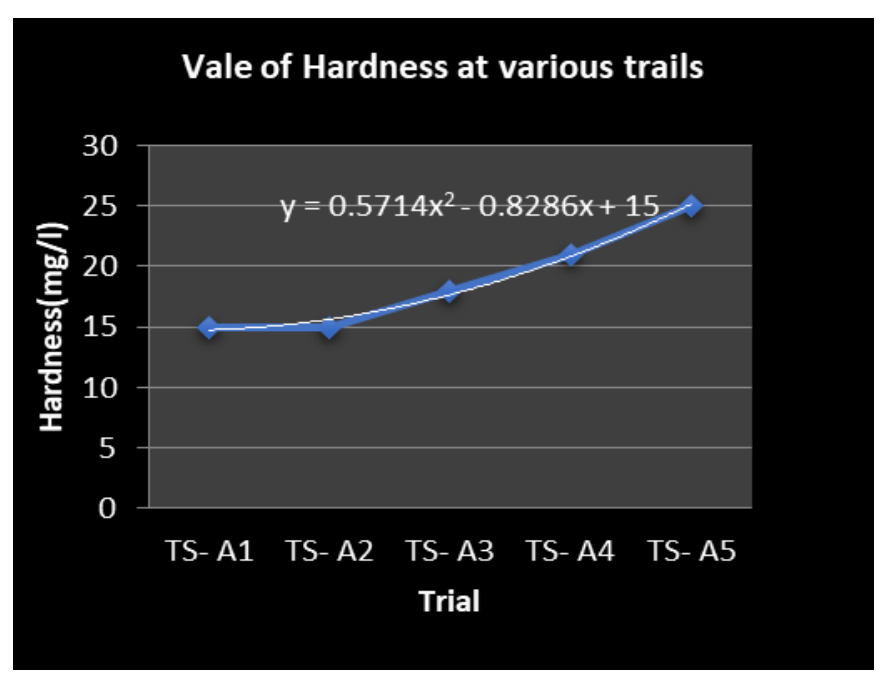

Fig 7.6Vale of Hardness at various trails

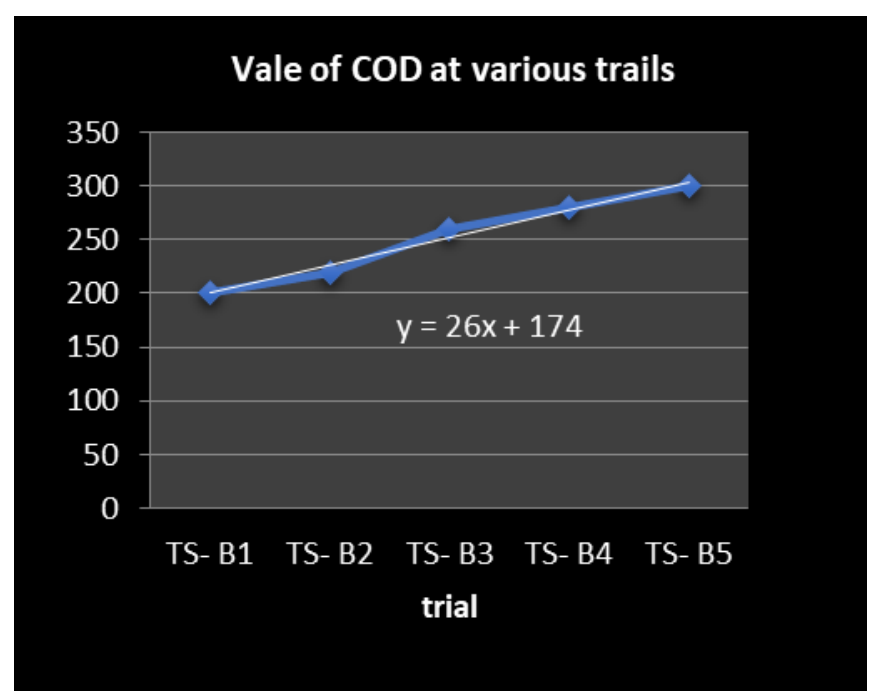

Fig 7.7Vale of COD at various trails

VIII. CORRELATION BETWEEN PH, TURBIDITY, E $_{\mathrm{C}}$ AND HARDNESS

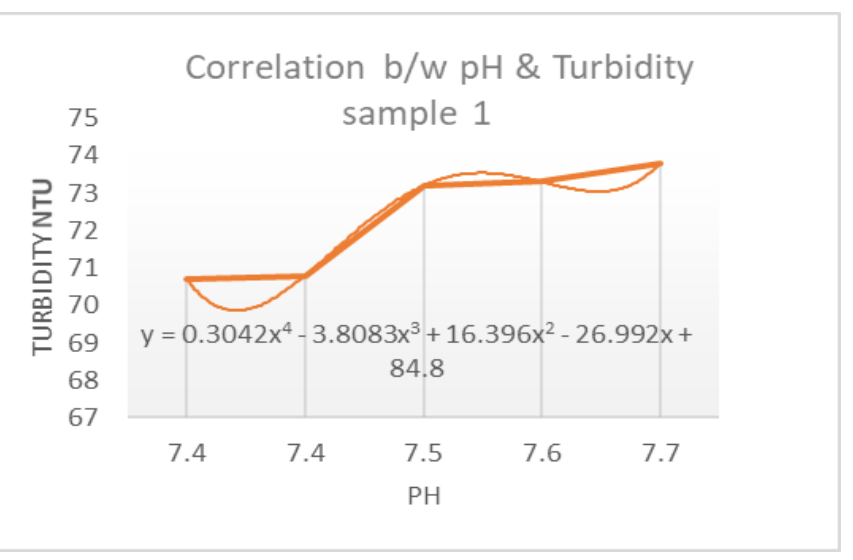

Fig 8.1Correlation b/w pH and Turbidity for Sample 1 
Fig 8.2Correlation b/w pH and Turbidity for Sample 2

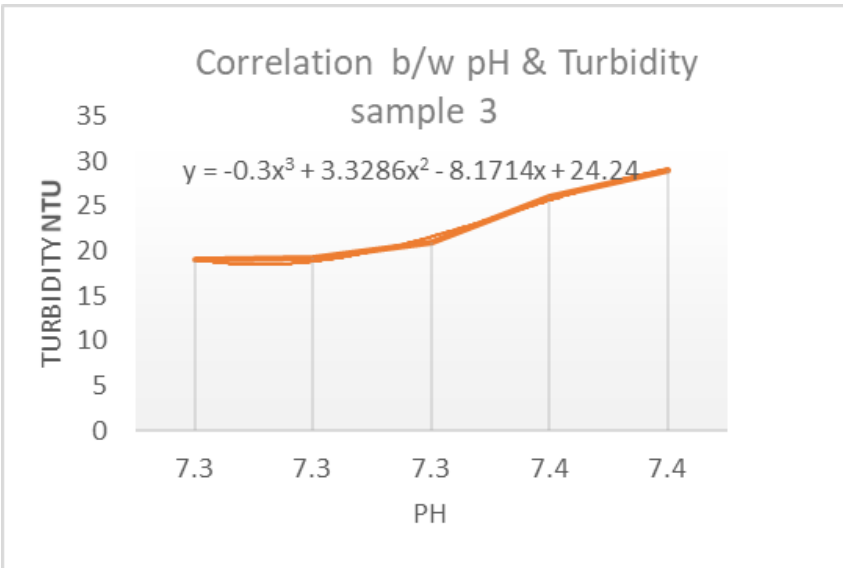

Fig 8.3Correlation b/w pH and Turbidity for Sample 3

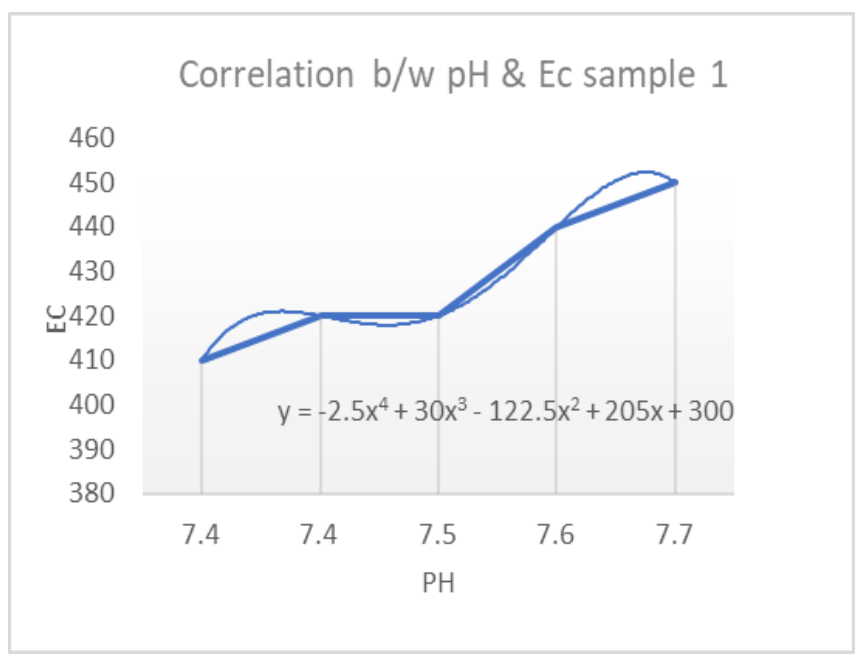

Fig 8.4 Correlation b/w pH and Ec for Sample 1

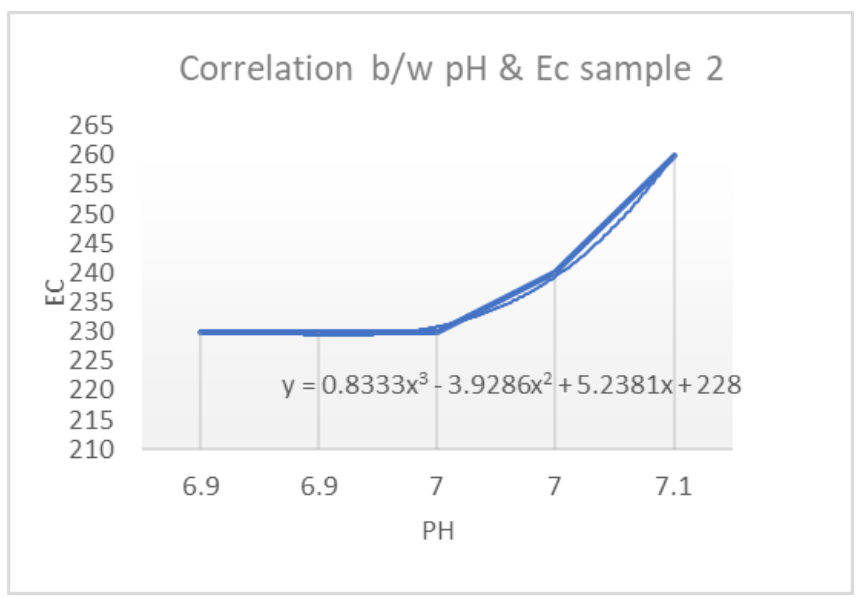

Fig 8.5 Correlation b/w pH and Ec for Sample 2

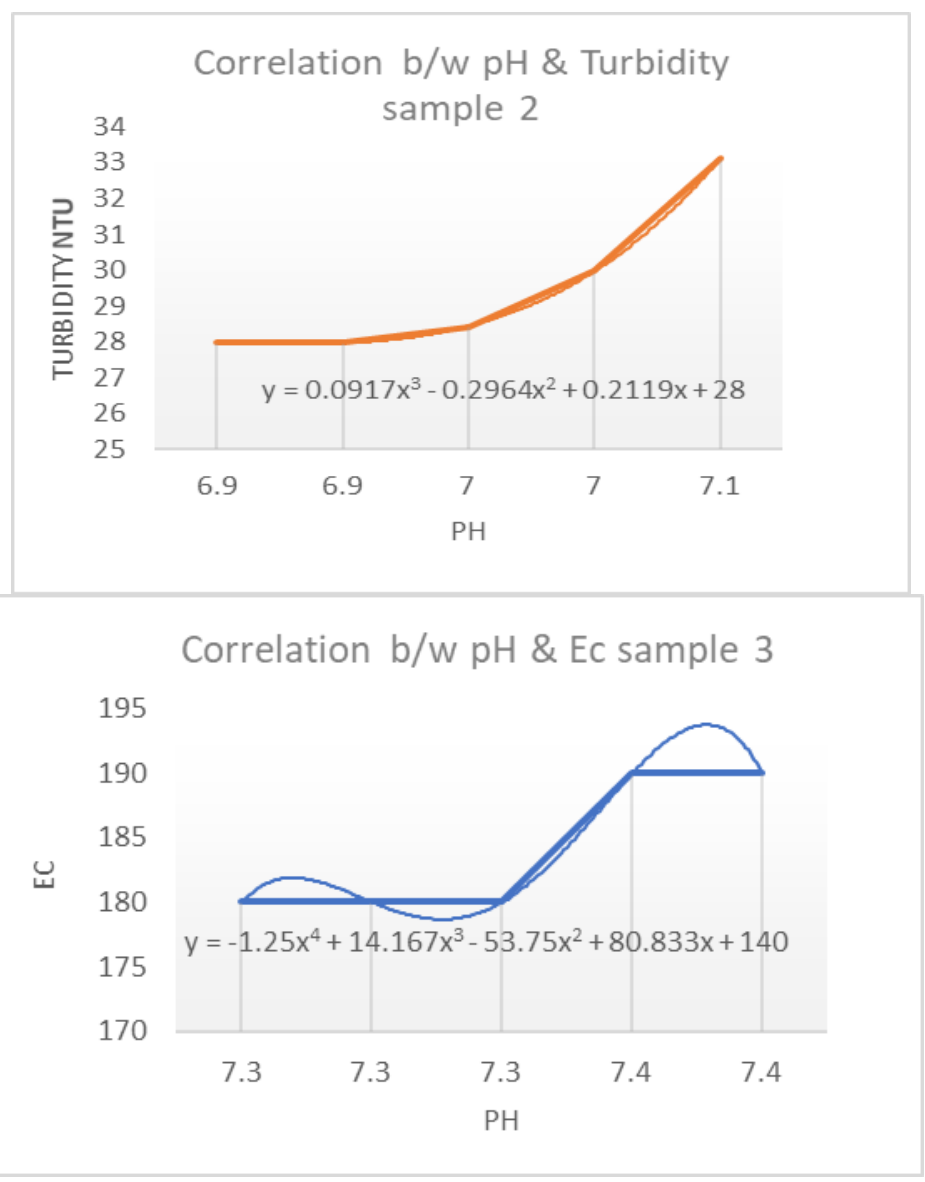

Fig 8.6 Correlation b/w pH and Ec for Sample 3

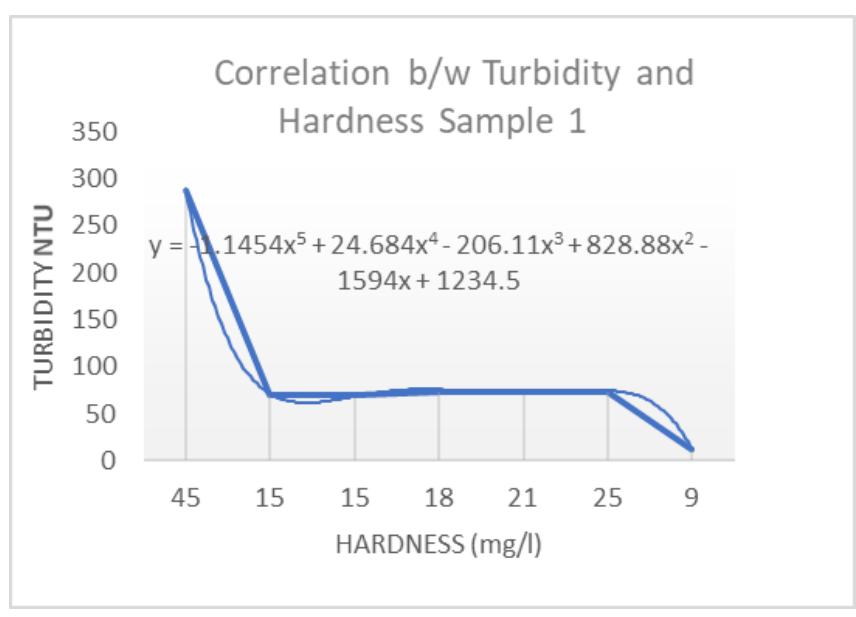

Fig 8.7 Correlation b/w Turbidity and Hardness for Sample 1 


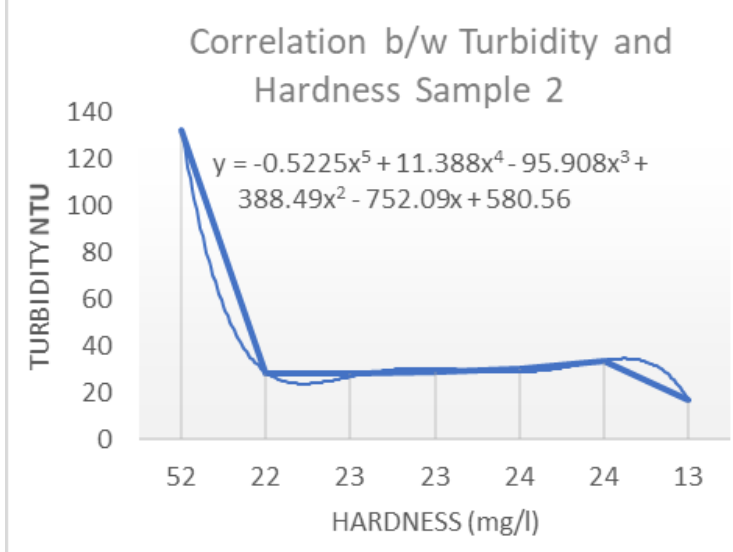

Fig 8.8 Correlation b/w Turbidity and Hardness for Sample 2

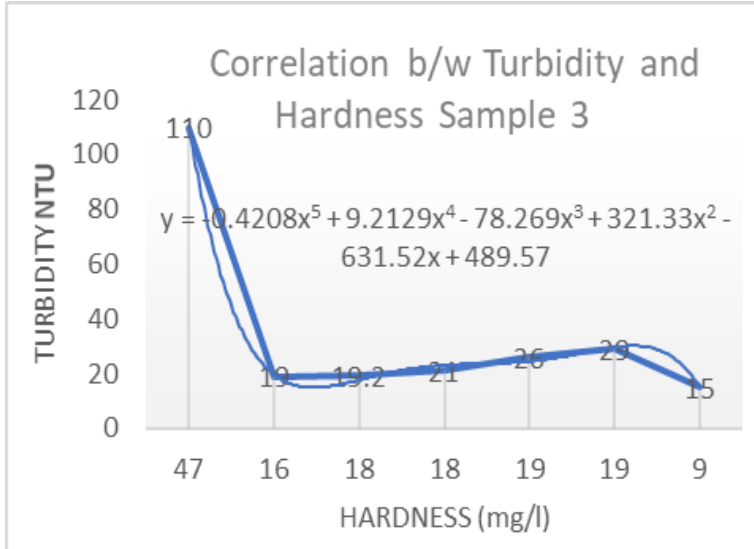

Fig 8.9 Correlation b/w Turbidity and Hardness for Sample 3

\section{TABLE 8.1 CORRELATION BETWEEN VARIOUS PARAMETERS AND ITS RELATION}

\begin{tabular}{|c|c|c|c|}
\hline Correlation & Sample & Equation & Relation \\
\hline \multirow[t]{3}{*}{$\begin{array}{l}\text { Correlation } \\
\text { b/w pH \& } \\
\text { Turbidity }\end{array}$} & 1 & $\begin{array}{l}y=0.3042 x^{4}- \\
3.8083 x^{3}+16.396 x^{2} \\
-26.992 x+84.8\end{array}$ & \multirow{3}{*}{$\begin{array}{l}\text { The relation } \\
\text { between the } \\
\text { pH \& } \\
\text { Turbidity are } \\
\text { they are } \\
\text { directly } \\
\text { proportional } \\
\text { to each other. } \\
\text { pH increases } \\
\text { with turbidity } \\
\text { increases }\end{array}$} \\
\hline & 2 & $\begin{array}{l}y=0.0917 x^{3}- \\
0.2964 x^{2}+0.2119 x \\
+28\end{array}$ & \\
\hline & 3 & $\begin{array}{l}y=-0.3 x^{3}+ \\
3.3286 x^{2}-8.1714 x \\
+24.24\end{array}$ & \\
\hline \multirow[t]{3}{*}{$\begin{array}{l}\text { Correlation } \\
\text { b/w pH \& } \\
\text { Ec }\end{array}$} & 1 & $\begin{array}{l}y=-2.5 x^{4}+30 x^{3}- \\
122.5 x^{2}+205 x+ \\
300\end{array}$ & \multirow{3}{*}{$\begin{array}{l}\text { The relation } \\
\text { between pH } \\
\text { and EC. They } \\
\text { are directly } \\
\text { proportional } \\
\text { to each other. } \\
\text { pH increases } \\
\text { with EC } \\
\text { increases. }\end{array}$} \\
\hline & 2 & $\begin{array}{l}y=0.8333 x^{3} \\
-3.9286 x^{2}+5.2381 x \\
+228\end{array}$ & \\
\hline & 3 & $\begin{array}{l}y=-1.25 x^{4}+ \\
14.167 x^{3}-53.75 x^{2}+\end{array}$ & \\
\hline
\end{tabular}

\begin{tabular}{|c|c|c|c|}
\hline & & $80.833 x+140$ & \\
\hline \multirow{3}{*}{$\begin{array}{l}\text { Correlation } \\
\text { b/w } \\
\text { Turbidity } \\
\text { and } \\
\text { Hardness }\end{array}$} & 1 & $\begin{array}{l}\mathrm{y}=-1.1454 \mathrm{x}^{5}+ \\
24.684 \mathrm{x}^{4}-206.11 \mathrm{x}^{3} \\
+828.88 \mathrm{x}^{2}-1594 \mathrm{x} \\
+1234.5\end{array}$ & \multirow{3}{*}{$\begin{array}{l}\text { The relation } \\
\text { between the } \\
\text { Hardness \& } \\
\text { Turbidity are } \\
\text { they are } \\
\text { directly } \\
\text { proportional } \\
\text { to each other. } \\
\text { Hardness } \\
\text { increases } \\
\text { with turbidity } \\
\text { increases }\end{array}$} \\
\hline & 2 & $\begin{array}{l}y=-0.5225 x^{5} \\
+11.388 x^{4} \\
-95.908 x^{3} \\
+388.49 x^{2}-752.09 x \\
+580.56\end{array}$ & \\
\hline & 3 & $\begin{array}{l}\mathrm{y}=-0.4208 \mathrm{x}^{5}+ \\
9.2129 \mathrm{x}^{4}-78.269 \mathrm{x}^{3} \\
+\quad 321.33 \mathrm{x}^{2} \\
631.52 \mathrm{x}+489.57\end{array}$ & \\
\hline
\end{tabular}

\section{CONCLUSION}

From the above discussion the following conclusion are drawn

- The result reported in the experimental study indicates the contaminants from the household waste water may be effectively removed by the rapid sand concept with activated carbon over the other conventional method.

- From this study high efficiency with low cost and economical way of treating raw water technologies were used. This is the one of the best ways to treat the house hold waste water and reusing.

- From this study physical method is sufficiently enough to treat, and emphrical values is derived to finding the value of respective.

\section{REFERENCES}

[1]. R.T.Pachkor and Dr.D.K.Parbat, "A Literature Review on Integrated Approach for Greywater Treatment", International Journal for Research in Applied Science \& Engineering Technology (IJRASET), Volume 5 Issue IV, April 2017 ISSN: 2321-9653.

[2]. C.Santos, F.Taveira-Pinto, C.Y.Cheng and D.Leite, "Development of an experimental system for greywater reuse", Desalination 285 (2012) 301-305

[3]. Fangyue Li, Knut Wichmann and Ralf Otterpohl, "Review of the technological approaches for greywater treatment and reuses", Science of the Total Environment 407 (2009) 3439-3449.

[4]. Shaikha Binte Abedin and Zubayed Bin Rakib, "Generation and Quality Analysis of Greywater at Dhaka City", Environmental Research, Engineering and Management, 2013. No. 2(64), P. 29-41 ISSN 2029-2139.

[5]. Nirmala.M.D., Muthukumar.K. and Ravikumar.G, "Review Of Greywater treatment methods", International Conference on Current Research in Engineering Science and Technology (ICCREST-2016).

[6]. Charles B. Niwangaba, Patrick Dinno, Issac Wamala, S.Sahar Dalahmeh, Cecilia Lalander and Hakan Jonsson, "Experiences on the implementation of a pilot grey water treatment and reuse based system at a household in the slum of Kyebando-Kisalosalo, Kampala", Journal Of Water Reuse and Desalination 0.04, 2014. 
[7]. Chidozie C Nnaji, Cordelia N mama, Arinze Ekwueme and Terlumun Utsev, "Feasibility of a Filtration-Adsorption Grey Water Treatment System for developing Countries", Hydrology Current Research 2013, ISSN 2157-7587.

[8]. Shobha Kundu, Isha P. Khedikar, Aruna M. Sudame, “Laboratory Scale Study for Reuse of Greywater", Journal of Mechanical and Civil Engineering (IOSR-JMCE), Volume 12, Issue 3 Ver.1 (May - June 2015) PP 40-47.

[9]. Adi Maimon, Eran Friedler and Amit Gross, "Parameters affecting greywater quality and its safety for reuse", Science of the Total Environment 487 (2014) 20-25.

[10]. Parameshwara Murthy.P.M., B.M.Sadasiva Murthy and Kavya.S, "Greywater Treatment \& Reuse: A Technological review", Global Journal for Research Analysis Volume-5, Issue-3, March-2016. ISSN No 2277-8160.

[11]. Karnapa Ajit, "A Review on Greywater Treatment and Reuse", International Research Journal of Engineering and Technology (IRJET), Volume:03 Issue:05, May-2016.

[12]. R.Saranya, S.Shanmugapriya and R.Subashini, "Experimental Study on Treatment Of Sullage Waste Water Using Coagulants", SSRG International Journal Of Civil Engineering- (ICRTCEMT-2017) April 2017.

[13]. A.Y.Katukiza, M.Ronteltap, C.B.Niwagaba, F.Kansiime and P.N.L.Lens, "Greywater treatment in Urban slums by a Filtration system: Optimisation of the filtration medium", Journal of Environmental Management 146 (2014) 131-141.

[14]. Mariah Siebert Zipf, Ivone Gohr Pinheiro and Mariana Gracia Cnegero, "Simplified greywater treatment systems: Slow filters of sand and slate waste followed by granular activated carbon", Journal of Environmental management 176 (2016) 119-127.

[15]. Shaikh, Sk Sameer and Sk Younus, "Greywater Reuse: A Sustainable Solution of Water Crisis in Pusad city in Maharastra, India", International Journal on Recent and Innovation Trends in Computing and Communication (Feb. 2015) Volume: 3 Issue: 2 ISSN: 2321-8169.

[16]. Zeev Ronen, Adriana Guerrero and Amit Gross, "Greywater disinfection with the environmentally friendly Hydrogen Peroxide Plus (HPP)", Chemosphere 78 (2010) 61-65.

[17]. J.S.Lambe and R.S. Chougule, "Greywater - Treatment and Reuse", Journal of Mechanical and Civil Engineering (IOSR-JMCE) ISSN: 2278-1684, PP: 20-26.

[18]. Marc Pidou, lisa Avery, Tom sephenson, Paul Jeffrey, Simon A. Parsons, Shuming Liu, Fayyaz A. Memon and Bruce Jefferson, "Chemical Solutions for Greywater Recycling", Chemosphere 71 (2008) $147-155$

[19]. E.Eriksson and E.Donner, "Metals in Greywater: Sources, presence and removal efficiencies”, Desalination 248 (2009) 271-278.

[20]. Lina Abu Ghunmi, Grietje Zeeman, Manar Fayyad and Jules B. Van Lier, "Greywater Treatment Systems: A Review"

[21]. Dr.Marc Pidou, Dr.Fayyaz Ali Memon, Prof. Tom Stephenson, Dr.Bruce Jefferson and Dr.Paul Jeffrey, "Greywater recycling: A review of treatment options and applications", Institution of Civil Engineers, Engineering Sustainability, Vol.160.

[22]. Sunil J. Kulkarni, Pallavi M. Kherde, "Research on Advanced Biological Effluent Treatment: A Review", International Journal of Research and Review, E-ISSN: 2349-9788: P-ISSN:2454-2237.

[23]. Prasant Tayde, Chaitanya Shastri, Bhoomi Shah, Nitesh Asabe, Dr. Hansa Jeswani, "Use of Sullage for Non-Potable Purpose", 2015 International Conference on Technologies for Sustainable Development (ICTSD-2015), Feb. 04-06, 2015.

[24]. Joseph B. Skudi, Ruth Wanjau, Jane Murungi and C.O.Onindo, “Alum Treated Greywater for Toilet Flushing, Mopping and Laundry work", Hydrology Current Research, Volume 2, Issue 2, ISSN: 2157-7587.

[25]. Mr.Amol Ashok Inamdar, "Sullage Water Treatment Technique", International Journal of Innovative studies in Sciences and Engineering Technology, Volume 2, Issue 12, ISSN 2455-4863.

[26].Long D.Nghiem, Nadine Oschmann, Andrea I.Schafer, "Fouling in greywater recycling by direct ultrafiltration", Desalination 187 (2006) 283-290.

[27]. J.G.March and M.Gual, "Studies on Chlorintion of Greywater", Desalination 249 (2009)317-322.

[28]. GideonP.Winward, Lisa M.Avery, Tom Stephenson and Bruse Jefferson, "Chlorine disinfection of greywater for reuse: Effect of organics and particles"" Water research 42 (2008) 483-491.

[29]. Sandhya Pushkar singh and Nusrat Ali, "Treatment of domestic wastewater by Rapid Sand Filter for Reuse in Irrigation Purpose",
International Journal for Scientific Research \& Development Vol. 4 , Issue 04, 2016 ISSN: 2321-0613.

[30]. J.de Koning, D.Bixio, A.karabelas, M.Salgot and A.Schafer, "Characterization and assessment of water treatment technologies for reuse", Desalination 218(2008) 92-104.

[31]. S.N.Ugwu, A.F.Umuokoro, E.A.Echiegu, B.O.Ugwuishiwu and C.C.Enweremadu, "Comparative Study of use of natural and artificial coagulant for the treatment of Sullage"

and treatment of greywater - a review"

[32]. P.Santhosh, D.Revanth and K.Saravanan, "Treatment of Sullage Wastewater by electro Coagulation using Stainless Steel Electrons",

[33]. J.K.Braga and M.B.A.Varesche, "Commercial Laundry Water Characterization", American Journal of Analytical Chemistry, 2014,5, 8-16

[34]. Golda A.Edwin, Poyyamoli Gopalswamy and Nandhivarmam muthu, "Characterization of domestic greywater from point source to determine the potential for urban residential reuse", Appl Water Sci (2014), 4:39-49.

[35]. Dilip M. Ghatidak, Kunwar D, Yadav “Characteristics and treatment of greywater-a review"

[36]. Anudeep nema, Kunwar D.Yadav and Robin A.Christian, "Effect Of Retention Time On Primary Media For Grey Water Treatment"

[37]. Bessy John and Bindhu.G, "Greywater treatment by Drawer Compacted Sand Filter with Silver coated Sand", International Journal of Science, Technology and Engineering, Volume 3, Issue 10, April 2017.

[38]. A.M. Kharwadea and Isha. P. Khedikar, "Laboratory Scale Studies On Domestic Grey Water Through Vermifilter and non-vermifilter", Journal of Engineering Research and Studies, E-ISSN0976-7916.

[39]. Dr.H.Karibasappa, A.Akila, N.Dhanabal, R.Dharani, K.Dhinesh, “An Experimental Investigation on Recycling of Grey Water Naturally by Using Canna Plants", International Journal of Innovative Research in Science, Engineering and Technology, Vol 6, Issue 3, March2017.

[40]. Anjali P Sasidharan1 and Meera V, "Performance evaluation of treatment of greywater by down-flow hanging sponge bio-tower using aerated aerobic sludge and microalgae chlorella", International Journal of Engineering Research and Science \& Technology, ISSN: 2319-5991, Vol 2 No 4 November 2013.

[41]. Oumar Sall ,Yukio Takahashi "Physical , chemical and biological characteristics of stored greywater from unsewered suburban Dakar in Senegal' Urban water journal vol 3, no 3,September 2006,153-164.

[42]. Sunil.J. Kulkarni , Ajaygiri K. Goswami "Application and advancement in treatment of wastewater by membrane", ISSN: 2277-9655

[43]. Andreas N. Angelkis, shane A. Snyder, "Wastewater treatment and reuse : past, present and future" ISSN: 2073-4441.

\section{AUTHORS PROFILE}

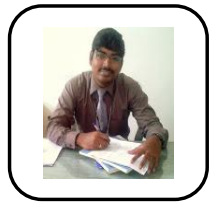

S. Christopher Gnanaraj, Working as a assistant professor in Department of Civil Engineering Kalasalingam Academy of Research and Education. He has a more than six years of teaching and research experience. His area of specialization is Structural Engineering and area of research is SCC, HSC, GPC \& EVS. He has published various papers in reputed journals in these areas. For any queries mail at christophergnanaraj@gmail.com

Ramesh Babu Chokkalingam completed his Ph.D. from IIT Chennai. He has more than ten years of experience in teaching and research. His areas of research includes pervious concrete, geopolymer concrete, and high volume flyash concrete. 
SKM.Pothinathan is a Assistant Professor in Department of Civil Engineeing at Kalasalingam Academy of Research and Education. He has taught number of courses in structural Engineering over the year, as well as more general courses on civil engineering. He holds a Masters in Structural Engineering and Bachelor in Civil Engineering under College affiliated to Anna University. He also a $\mathrm{PhD}$ candidate at the Kalasalingam Academy of Research and Education. His areas of interest and research are in the fieild of concrete technology.

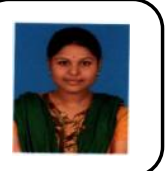

R.Rekha completed her B.tech in Civil Engineering from Kalasalingam Academy of Research and Education. Her area of interest is environmental engineering and construction management. She has modest publications in reputed journals. 